\title{
Entrepreneurship in the Context of the Resource-Based View of the Firm
}

\author{
Foss, Nicolai J.
}

Document Version

Final published version

Publication date:

2011

License

CC BY-NC-ND

Citation for published version (APA):

Foss, N. J. (2011). Entrepreneurship in the Context of the Resource-Based View of the Firm. Institut for Strategic Management and Globalization. SMG Working Paper No. 8/2011

Link to publication in CBS Research Portal

\footnotetext{
General rights

Copyright and moral rights for the publications made accessible in the public portal are retained by the authors and/or other copyright owners and it is a condition of accessing publications that users recognise and abide by the legal requirements associated with these rights.

\section{Take down policy}

If you believe that this document breaches copyright please contact us (research.lib@cbs.dk) providing details, and we will remove access to the work immediately and investigate your claim.
} 
Entrepreneurship in the Context of the Resource-based View of the Firm

Nicolai J. Foss

SMG WP 8/2011

January, 2011 
SMG Working Paper No. 8/2011

January, 2011

ISBN: 978-87-91815-70-6

Department of Strategic Management and Globalization Copenhagen Business School

Porcelænshaven 24

2000 Frederiksberg

Denmark

www.cbs.dk/smg 


\title{
ENTREPRENEURSHIP IN THE CONTEXT OF THE RESOURCE-BASED VIEW OF THE FIRM
}

\author{
Nicolai J. Foss \\ Department of Strategic Management and Globalization \\ Copenhagen Business School \\ Porcelainshaven 24; 2000 Frederiksberg; Denmark \\ njf.smg@,cbs.dk \\ Prepared for Kevin Mole and Monder Ram, eds., \\ Perspectives in Entrepreneurship. Palgrave.
}

23. January, 2011

Keywords: Strategic management, the resource-based view, entrepreneurship JEL Code: L21, L26

\begin{abstract}
This chapter discusses entrepreneurship in the context of the RBV. What does the RBV have to say that the study of entrepreneurship may usefully draw on? And, conversely, how can entrepreneurship research further the RBV? I begin by sketching the RBV. I then discuss the relation between the RBV and entrepreneurship research, before I characterize a new research stream that has emerged over the last decade or so in the intersection of the RBV and entrepreneurship research, namely "strategic entrepreneurship."
\end{abstract}




\section{INTRODUCTION}

Strategic management is ultimately about how to best deploying input factors to serve markets in ways that result in high levels of value creation from the interaction between the firm and its customers, and simultaneously making sure that the firm actually appropriates a substantial share of the created value. If a firm has a potential to do this better than the competition and on a long-terms basis, it is said to possess a "sustained competitive advantage"? But, where do such advantages come from? Who creates them and how? What is the context for their emergence?

While competitive advantage has traditionally been addressed by strategic management research (and industrial economics), the latter questions are more in focus in entrepreneurship (and the economics of entrepreneurship), where they are linked to the notion of pursuing opportunities. In turn, according to entrepreneurship scholars this pursuit will often involve forming a new firm. Entrepreneurs are people who believe that they are better informed than other people and exploit their supposed informational advantage in the pursuit of opportunities for profit.

Though complementary, the two fields have their own research traditions, speak to different audiences, pose different questions, and so on. In this chapter, I discuss the relation between strategic management, specifically the resource-based view (the "RBV"), and entrepreneurship. What are their relationships? What has been done to integrate the two fields? What can be done? How will practising managers benefit from a closer integration? I take a basic knowledge of entrepreneurship theory as a given and relate this theory to the RBV.

The RBV is the dominant view in strategic management (Newbert, 2007; Acedo, Barroso, \& Galan, 2006), Moreover, it has influenced a number of other fields in management research, such as international management, technology management, HR management, and organization theory. There is little doubt that it has had significant effect on managerial practice, if mainly through related ideas on core competencies, capabilities, and so on. The RBV encompasses a broad set of 
ideas. Thus, some use the term in a narrow sense for a set of ideas based on mainstream economics about what are the necessary conditions for sustained competitive advantage. Others use it more broadly for all approaches that somehow trace firm performance to firm "resources," broadly conceived, including ideas on "dynamic capabilities," "core competencies" and "capabilities" that draw on more heterodox ideas in economics, cognitive science insights and sociology.

The origins of the RBV are often found in the work of Edith Penrose (1959) who explained how firms may diversify in a related manner based on excess firm-specific resources, argued that different firms would learn to extract different services from the same kind of resources, and emphasized that what are "productive opportunities" to a firm lies in the eyes of the top management team (e.g., Kor \& Mahoney, 2000). Another precursor of the RBV is economist Harold Demsetz (e.g., 1973, 1982) whose work in industrial economics stressed, among other things, how firm-specific advantages could drive, simultaneously, a tendency towards increasing industrial concentration and high returns (i.e., concentration does not cause high returns, as claimed by traditional industrial organization economics). Demsetz also explained how such advantages may derive from superior information.

Note how Penrose and Demsetz suggest ideas that would seem to be close to the phenomenon of entrepreneurship: Both Penrose and Demsetz trace (superior) performance to unique insights that are not necessarily easily imitated. Specifically, Demsetz (1973: 3) attributes superior performance to the "combination of great uncertainty plus luck or atypical insight by the management of a firm." Similarly, entrepreneurship research in economics and management see entrepreneurs are people who believe that they have lower information costs than other people (Casson \& Wadeson, 2007), and/or privileged information about, for example, the future preferences of consumers (Knight, 1921; Mises, 1949; Rumelt, 1987). Entrepreneurship consists in using such privileged information to exercise decisions over the use of resources in servicing markets so as to seize opportunities, that 
is, hitherto unrecognized possibilities of seizing a profit. Thus, one would expect the relation between the RBV and the entrepreneurship fields to be a very close one. However, this is hardly the case; specifically, at least until recently, the two research streams have developed rather independently.

In the following, entrepreneurship is considered in the context of the RBV. What does the RBV have to say that the study of entrepreneurship may usefully draw on? And, conversely, how can entrepreneurship research further the RBV? I begin by sketching the RBV. I then discuss the relation between the RBV and entrepreneurship research, before I characterize a new research stream that has emerged over the last decade or so in the intersection of the RBV and entrepreneurship research, namely "strategic entrepreneurship."

\section{THE RESOURCE BASED VIEW OF STRATEGY:}

\section{CONTENT AND FOUNDATIONAL ASSUMPTIONS}

\section{Strategic Management and Economics}

Ultimately, strategic management is about creating and maintaining "sustained competitive advantage" (SCA). Strategies may be defined as plans for creating SCA. SCA is thus the central thing that strategic management scholars seek to explain, or, if you like, the central dependent variable in strategy research. It may be defined as a firm's ability to create and appropriate more value than the competition on a sustained basis. In other words, SCA is usually interpreted as a firm-level phenomenon, that is, as something that somehow emerges from the interaction of members of the coalition of input owners (owners of financial, physical and financial capital) that defines the and is jointly held by thís coalition. Note that possessing a SCA does not necessarily translate into superior financial performance; SCA is rather a potential for such performance, which may or may not be realized. 
Almost since its inception in the late 1960s, strategic management has been heavily indebted to economics, particularly the mainstream economics of intermediate micro-economics textbooks (i.e., "Marshallian price theory"), industrial organization economics, and financial economics. ${ }^{1}$ This is hardly surprising: Central, arguably the central, constructs of strategic management—namely, value creation, value appropriation and sustained competitive advantage - lend themselves directly to an economics interpretation. The notion that all of strategic management ultimately boils down to creating and appropriating more value than the competition (e.g., Peteraf \& Barney, 2003) can be usefully addressed in terms of very basic economics. The tools of industrial organization theory, game theory, and bargaining theory can be applied to refine the analysis (e.g., Makadok, 2010).

In fact, at its core most modern strategic management theory (whether the RBV or the positioning approach of Porter, 1980) is based on a logic of "competitive imperfection". This means that, ultimately, some deviation from the ideal of the perfectly competitive model of economics, explain the central phenomenon that strategy is concerned with, namely sustained competitive advantage. In the Porter (1980) approach these imperfections stem from barriers to entry at the level of industries or strategic groups within industries. Such barriers mean that are protected by the can gain market power, raising prices, and giving rise to profits. $^{2}$

\section{The Resource-based View}

In its modern version, the RBV was developed in a string of seminal contributions by Lippman and Rumelt (1982), Wernerfelt (1984), Rumelt (1984) and Barney (1986).The RBV is often presented as a "theory of the firm." This is somewhat imprecise, given that nowadays a theory of the firm usually means a theory of the existence and scope of firms (Coase, 1937; Williamson,

\footnotetext{
${ }^{1}$ Excellent discussions of the influence of economics on strategic management can be found in Porter (1981), Rumelt, Schendel and Teece (1991), Hoskission, Hitt, Wan and Yiu (1999), and Lockett and Thompson (2001).

${ }^{2}$ As well as introducing welfare losses. Thus, superior performance and harm done to society are two sides of the same coin in this approach. In contrast, in the RBV lens superior performance and increasing welfare are two sides of the same coin.
} 
1996). The RBV is not a theory of the firm in this sense. It would be more correct to say that the RBV is first and foremost a theory of SCA.To repeat SCA refers to the potential of a firm to create and appropriate more value than the competition. This raises the issue of what may be meant by the "competition." If this is taken to include all other firms, only one firm in an industry can hold SCA. However, in some formulations, SCA is defined relative to the marginal firm, that is, the firm that exactly breaks even (Peteraf \& Barney, 2003). An additional issue is what is meant by "creating and appropriating value." Briefly, a firm creates value when it creates producers' and/or consumers' surplus (i.e., $\mathrm{P}-\mathrm{C}>0$ and/or $\mathrm{P}-$ reservation prices $>0$ ). It appropriates value when it can capture parts of these surpluses. The better the firm is at capturing such surpluses, the higher its financial performance.

The RBV is characterized by tracing the potential to create and appropriate more value than the competition to the resource endowments of firms, and the characteristics of these resources. The crowning achievement of the high church RBV has been the formulation of criteria that must be jointly met for resources to give rise to sustained competitive advantage (Barney, 1991; Peteraf \& Barney, 2003; Peteraf, 1993). The seminal contribution in this regard is Jay B. Barney's 1991 article, "Firm resources and sustained competitive advantage", one of the most influential strategic management texts ever. Barney (1991: 102) explains that

A firm is said to have a competitive advantage when it is implementing a value creating strategy not simultaneously being implemented by any current or potential competitors. A firm is said to have a sustained competitive advantage when it is implementing a value creating strategy not simultaneously being implemented by any current or potential competitors and when these other firms are unable to duplicate the benefits of this strategy. 
(Note how economics underlies the analysis: SCA is defined in terms of situations in which all attempts by competitor firms at imitating or substituting a successful firm have ceased, that is, when Nash equilibrium obtains). SCA can be enjoyed by firms, Barney explains, that control resources that are valuable, rare, and costly to imitate and substitute. These conditions make up what has become known as the "VRIN framework," or, adding the organizational ("O") embeddedness of resources, the "VRIO framework."

Barney (1991) is not entirely forthcoming about the precise meaning of these criteria (Foss \& Knudsen, 2003). He talks about "value" in terms of being able to exploit an opportunity or neutralize a threat in the environment (i.e., the SWOT framework), and hints that "environmental analysis" (e.g., Porter's 5-forces framework) may be useful for understanding the criterion of value. Somehow, of course, value is a matter of driving a wedge between the reservation prices (i.e., the maximum willingness to pay of the customers) of the products made possible by the relevant resource and the costs of production of those products. However, how exactly that wedge arises is basically not discussed in Barney (1991), and is implicitly seen as covered in other approaches ${ }^{3}$ A firm that possesses valuable resources may deploy these resources to executing a strategy "not simultaneously being implemented by any current or potential competitor," that is, it has competitive advantage. Whether that competitive advantage is sustainable depends on the three other criteria (RIN or RIO). The criterion of "rare'ness" should be understood in a simple counting sense (implying that not "too many" other firms can implement the same strategy(ies) as the firm enjoying a sustained competitive advantage), and the two remaining criteria refer to the costliness of imitating or substituting the resource or bundle of resources that give rise to the competitive advantage.

\footnotetext{
${ }^{3}$ Not only in strategy, but also in, for example, HRM and organization which has implications for the efficiency (costs) with which resources are organized (Barney, 1995), or marketing, which addresses the maximum prices (i.e., reservation prices) that consumers/customers/clients are willing to pay.
} 
Earlier work by Barney (1986) established the necessary condition for sustained competitive advantage that the relevant underlying resources or the services thereof are acquired or rented at a price that is lower than their net present value. Otherwise, any competitive advantages will be offset by supply prices on "strategic factor markets." This is explicitly included in Peteraf's (1993) closely related contribution, which introduces a condition of relative immobility of resources: essential but highly mobile resources can appropriate most or all of the value they contribute to the firm. Peteraf (1993) also includes resource heterogeneity of resources (this is captured by the "valuable" and "rare" conditions in the Barney framework), "ex ante limits to competition" (this is Barney's [1986] condition that resources must be purchased at a $\mathrm{p}<$ NPT to be of strategic value), and "ex post limits to competition" (this is Barney's [1991] conditions of costly imitability and substitutability).

\section{Extensions of the Basic RBV Model}

Much subsequent work on the RBV has consisted in elaborating, refining, extending and testing the core ideas of the RBV as well as refining the more specific criteria for sustained competitive advantage.

Resource accumulation. A central question in the RBV is what factors make resources hard to imitate. The seminal contribution here is the resource accumulation model advanced by Dierickx and Cool (1989). They argue that competitive advantages stem from firm-specific resource stocks that need to be accumulated internally. Strategists are mainly concerned with the building of valuable stocks of resources (like brand reputation, manufacturing capabilities, technological expertise) by making appropriate choices about strategic investments flows. The imitability and sustainability of competitive positions result from the characteristics of the mapping of investment flows onto resource stocks. Dierickx and Cool argue that time compression diseconomies explain

\footnotetext{
${ }^{4}$ In terms of the VRIN framework this may be seen as built into the "V(alue" criterion: If the price of a resource is equal to its NPV, it has no value to the firm.
} 
early-mover advantages, since higher investment outlays over a shorter period of time by a follower are required to catch up with an early-mover. Asset mass efficiencies confer an advantage to a firm that has already accumulated a critical mass of a resource (cf. Cohen \& Levinthal 1990). However, in the presence of asset erosion, Knott et al. (2000) argue and show empirically that time compression diseconomies and asset mass efficiencies are not sufficient to gain sustainable competitive advantages.

Rather, the interconnectedness of asset stocks and causal ambiguity appear to be necessary to explain long-term differences in resource stocks (Lippman \& Rumelt 1982; Barney 1991). The value of an asset stock depends on the presence of complementary resources, sharply increasing the investment costs for an imitator. Causal ambiguity obfuscates the link between resources and firm performance. It points to the tacitness, complexity, and specificity of the resource base (Reed \& DeFillippi, 1990). Recent work has particularly highlighted the complexity of a firm's resource base as an effective barrier to imitation (Winter, 2000; Rivkin, 2000). Many scholars argue that knowledge-based assets such as firm-specific capabilities are particularly likely to meet these criteria, because these have emerged through complex and path-dependent historical processes and embody a great deal of knowledge that is costly to articulate (Barney, 1991; Winter, 2000). ${ }^{5}$

These characteristics also impact the tradability of resources. Thus, while generic resource may be acquired in factor markets, the firm-specific and idiosyncratic resources underpinning competitive advantages result from internal accumulation processes. Lippman and Rumelt (2003a: 1082) succinctly summarize RBV's insistence on the primacy of internal resource accumulation:

The resource-based view predicts that firms will focus their energies on the development of complex "home-grown" resources, taking time and care to develop

\footnotetext{
${ }^{5}$ Note, however, causal ambiguity of its resources may also restrict the strategic options of a firm, since it may find it impossible to transfer or to replicate the competitive advantage in a different context (Winter \& Szulanski 2001; King \& Zeithamel 2001).
} 
knowledge, know-how, social capital, and other socially complex, difficult-to-transfer resources.

However, Makadok (2001a,b) argues that resource development may not constitute the only causal mechanism to explain competitive advantages. Firms may also be better than others at picking undervalued resources in the market for resources. Resource-picking points to the role of strategic factor markets in explaining firm behavior and competitive advantage.

Strategic factor markets. Barney (1986) characterized markets for resources as strategic factor markets. Apart from luck, firms may only acquire resources below their net present value by forming heterogeneous expectations about resource value. Otherwise, prospective buyers bid up the price to the resource's net present value and the seller appropriates the value from the resource (e.g., Capron \& Shen, 2007). Much subsequent research on strategic factor markets has focused on the origins of differential expectations about resources. Makadok and Barney (2001) analyze differences in the information acquisition strategies of firms, while Denrell, Fang and Winter (2003) point to entrepreneurial serendipity to explain the acquisition of undervalued resources. A second line of inquiry has focused on co-specialization among heterogeneous resources (Teece 1986; Lippman \& Rumelt 2003; Adegbesan 2009). Even with perfect information, heterogeneous firms may place differential values on a complementary resource in a strategic factor market. With resource heterogeneity among buyers, gains from resource trade are not dissipated in a competitive bidding process and at least some of the resource value is appropriated by the buyer.

Bargaining. Work on strategic factor markets point to the more general problem of bargaining resource owners (Peteraf, 1993). Bargaining among resource owners has attracted a great deal of attention in recent contributions to the RBV. Coff $(1997,1999)$ argues that value appropriation among resource owners (e.g. employees, shareholders, suppliers) fundamentally depends on the bargaining power of each resource owner. He shows how various instantiations of 
constrained resource mobility systematically influence the bargaining position of resource owners. Lippman and Rumelt (2003a) and Adgbesan (2009), draw on cooperative game theory to analyze how co-specialization among resources systematically change the outside options for resource owners and thereby determines their relative bargaining positions. MacDonald and Ryall (2004) add to this emerging stream of literature by establishing the necessary conditions for value appropriation. They highlight the importance of competition for a scarce resource among different resource coalitions for value appropriation. Blyler and Coff (2003) add a social dimension to the bargaining problem by stressing the role of social capital for attaining and leveraging bargaining power.

\section{Empirical Work}

Despite its broad theoretical appeal and strong influence on managerial education and practice, the empirical track record of the key tenets of the RBV has so far been somewhat modest (Priem \& Butler 2001a,b). Madsen and Hoopes (2008) argue that the RBV lacks a cumulative body of work showing how firms differ in their resource bases. In survey articles on the empirical support for the RBV, Armstrong and Shimizu (2007) and Newbert (2007) find only modest support for the key tenets of the RBV that connect resource characteristics to sustained profitability (cf. Crook et al. 2008 for a meta study that finds more robust support). Arend (2006) argues that resources that meet the VRIO criteria are usually identified only ex post, making the explanation circular; (2) the $\mathrm{RBV}$ is mainly used as a convenient framing device and specific implications of the view are seldom tested; (3) the link between resources and performance is not carefully examined, for example, in terms of organizational variables that mediate this link; (4) key resources are hard to measure, particularly those "socially complex" and "tacit" resources that the view often focuses on (e.g., Dierickx \& Cool, 1989; Barney, 1991); and (5) the gains from superior resources may not be 
captured at the firm level—but rather be captured by individual resources (Coff, 1997, 1999; Lippman \& Rumelt, 2003) — in which case firm performance cannot be the dependent variable.

\section{Other Resource-based Research Streams}

The above resource-based ideas constitute what may be seen as the core of the RBV. These are ideas that primarily draw on mainstream economics. However, many of the ideas that have popped up in the evolution of the RBV are not so easily aligned with, for example, the basic microeconomics, such as notions involving process, learning, innovation, evolution, and tacit knowledge. Research streams closely related to the core RBV have emerged to deal with these more dynamic issues. They encompass the "knowledge-based view of the firm" (Kogut \& Zander, 1992), the "evolutionary theory of the firm" (Nelson \& Winter, 1982), the "capabilities view of the firm" (Langlois, 1992), and the "dynamic capabilities view” (Teece, Pisano, and Shuen, 1997). These streams, which Gavetti and Levinthal (2004) call the "low-church RBV," draw on the product development and knowledge management literatures in management, evolutionary economics, Schumpeterian thought, the organizational learning literature, work on leadership and alliances, and business history.

While overall there is the same emphasis on firms as collections of heterogeneous resources, the low-church RBV focuses on building, accumulating, transforming, managing, learning about, combining and recombining, etc. resources, and, in particular, the services that can be derived from such resources. Dynamics and learning are heavily emphasized. Moreover, the low church RBV unambiguously concentrates on resources or assets that are knowledge-based, social in the sense that they are somehow linked to a collectivity of interacting agents, and tend to put much emphasis on the tacit nature of the knowledge that is alleged to reside in such interaction.

A particularly influential contribution is Teece, Pisano and Shuen's (1997). They argue that superior performance comes from a firm's capacity to change its resource base in the face of 
Schumpeterian competition and environmental change. Dynamic capabilities are defined as the firm's ability to integrate, build, and reconfigure internal and external competences to address rapidly changing environments (Teece, Pisano \& Shuen 1997: 516). Importantly, dynamic capabilities reflect past learning processes, as they are a learned pattern of collective activity through which the organization systematically generates and modifies its operational routines in pursuit of improved performance. This basic definition has been subsequently refined and extended, but what unites different approaches and definitions is the insistence on an organizational ability to alter its resource base. Thus, Helfat et al. (2007: 4) synthesize prior conceptual work by defining a dynamic capability as "the capacity of an organization to purposefully create, extend, and modify its resource base". Accordingly, dynamic capabilities may perform different tasks that alter the resource base, such as new product development, alliance formation, or post-acquisition integration (Eisenhardt \& Martin, 2000).

Recent work on dynamic capabilities has increasingly stressed the role of organizational processes for understanding how firms alter its resource base. Teece (2007) opens up the black box of dynamic capabilities by relating the concept to organizational processes of sensing and seizing business opportunities and the constant (re)alignment of resources (cf. Helfat \& Peteraf, 2009). A firm's sensing ability critically depends on the organizational systems and individual capacities to learn and to identify, filter, evaluate, and shape opportunities. Once a business opportunity is identified, the organizational structure, procedures, and incentives influence whether and how a firm seize the opportunity and creates a new strategic path.

THE RESOURCE-BASED VIEW AND ENTREPRENEURSHIP: WHAT ARE THE CONNECTIONS?

\section{What is Entrepreneurship?}


In the entrepreneurship curriculum of many business schools, the phenomenon under investigation has often been "small-business management." Entrepreneurs are pictured as the managers of small, family-owned businesses or start-up companies. Entrepreneurship consists of routine management tasks, relationships with venture capitalists and other sources of external finance, product development, marketing, and so on. Unfortunately, this notion of entrepreneurship is sufficiently elastic to be practically meaningless. It appears to include virtually all aspects of small or new business management, while excluding the identical tasks when performed within a large or established business. Put differently, if entrepreneurship is simply a set of management activities, or any management activity that takes place within a particular type of firm, then it is unclear why we should bother to add this label to those activities.

It is, in fact, common, particularly within the management literature, to associate entrepreneurship with boldness, daring, imagination, or creativity (e.g., Lumpkin and Dess, 1996). These accounts emphasize the personal, psychological characteristics of the entrepreneur. Entrepreneurship, in this conception is a specialized activity that some individuals are particularly well equipped to perform. Probably the best-known concept of entrepreneurship in economics is Joseph Schumpeter's idea of the entrepreneur as innovator. Schumpeter's entrepreneur introduces “new combinations"- new products, production methods, markets, sources of supply, or industrial combinations - shaking the economy out of its previous equilibrium through a process Schumpeter termed "creative destruction." Entrepreneurship can also be conceived as "alertness" to profit opportunities. This concept has been elaborated most fully by Israel Kirzner (1973) who follows Austrian economist Friedrich Hayek (1968) in describing competition as a discovery process: the source of entrepreneurial profit is superior foresight, the discovery of something (new products, cost-saving technology) unknown to other market participants. The simplest case is that of the arbitrageur, who discovers a discrepancy in present prices that can be exploited for financial gain. 
In a more typical case, the entrepreneur is alert to a new product or a superior production process and steps in to fill this market gap before others.

Success, in this view, comes not from following a well-specified maximization problem, but from having some knowledge or insight that no one else has, notably in future changes in technologies, preferences, regulation, new markets, new sources of supply and so on. As Salerno (1993: 123) argues, entrepreneurs "are those who seek to profit by actively promoting adjustment to change. They are not content to passively adjust their . . . activities to readily foreseeable changes or changes that have already occurred in their circumstances; rather, they regard change itself as an opportunity to meliorate their own conditions and aggressively attempt to anticipate and exploit it." In generating superior foresight, entrepreneurs rely on the knowledge they hold. Thus, Shane (2000) demonstrates how experiential knowledge, which he takes to include "prior knowledge about markets," "prior knowledge about how to serve markets," "prior knowledge of customer problems," etc., influences the opportunities that entrepreneurs discover.

A general understanding of entrepreneurship that integrates the above notions, and used in the following is that entrepreneurship is the exercise of ability and willingness to perceive new economic opportunities and to introduce specific ways of seizing these opportunities into the market in the face of uncertainty (Knight, 1921; Wennekers \& Thurik, 1999).

\section{The RBV and Entrepreneurship}

Given the above characterization of entrepreneurship, it would immediately seem that there are multiple connections to the RBV. Like the RBV, entrepreneurship is about exploiting superior information or insight for the purpose of earning a profit, preferably over an extended period of time. Thus, entrepreneurial outcomes are also competitive outcomes, that is, they lead to the production of goods or services at lower costs or qualitities that are higher than those of the competition (Mosakowski, 1998: 626). In order to exploit an opportunity, an entrepreneur usually 
has to assemble a set of resources, at least one of which (namely his own specific insight) is specialized to the opportunity. He will often have to modify the resource-base as he pursues the opportunity. The insight is sometimes so much inside the head of the entrepreneur that he may find it difficult to communicate to outside parties, such as venture capitalists and other financiers. As stressed in the "effectuation approach" of Sarasvathy (2008), entrepreneurs usually don't begin from an analytical industry or segment analysis á la Porter or Kotler; they begin with the resources, including network contacts, that they have "at hand." Similarly, the RBV stresses that strategy begins from an analysis of the resources that the firm controls rather than from Porterian industry analysis (Barney, 1986).

Thus, idiosyncracy, tacit knowledge, uncertainty, dynamics, resource assembly and changes in the resource-base seem central to entrepreneurship-as it does to resource-based strategy! As RBV scholar Kathleen Conner (1991: 133-134) perceptively noted two decades ago:

In a resource-based view, discerning appropriate inputs is ultimately a matter of of entrepreneurial vision and intuition: the creative act underlying such vision is a subject that so far has not been a central focus of resource-based theory development.

Given this, it is somewhat surprising that the RBV and entrepreneurship research have, in fact, made rather little contact.

\section{Never the Twain Shall Meet?}

However, there are some good reasons for this lack of contact. Consider first the situation from the point of view of the RBV. The key point of interest in the RBV sustained competitive advantage, that is, a firm's (note: not an entrepreneur's) ability to create and appropriate more value than the competition on a sustained basis. First, notice that this means that the RBV is primarily about outlier firms, those few exceptional firms that actually are persistently successful. In contrast, the entrepreneurship is about the creation of any firm, from the mon \& pop store on the corner to a 
new breakthrough corporation based on cutting-edge theory. And some would argue that the entrepreneurship field is really about any entrepreneurial act, by individuals or firms, whether emerging or established. Second, various lists have been compiled of the criteria that resources must meet in order to yield rents in equilibrium (e.g., the VRIN criteria of Barney, 1991). However, there is a retrospective character to such lists: Their main function is to perform a kind of sort among the firm's resources to see if any conform to the criteria. Equipped with the list, a manager can ascertain every resource in the firm to check if any of them conform to the criteria on the list. However, the list does not explicitly tell a manager how to go about creating strategic resources. Also, the list is not a guide to the identification of opportunities, the exploitation of which may later be turned into advantages; in contrast, entrepreneurship is all about being forward-looking. Thus, the core RBV analysis simply lacks a story about the creation of competitive advantage. All it seems to have is the admonition that managers should try and use their superior inside information so as to pick those resources in strategic factor markets that are currently undervalued (cf. Rumelt, 1987; Makadok, 2001; Denrell, Fang \& Winter, 2003). ${ }^{6}$

Now consider the situation from the point of view of the entrepreneurship field. Entrepreneurship research has characteristics, even biases, namely it concentrates on new firm formation (start-ups), it focuses on individual entrepreneurs, and it highlights the discovery activities of these individuals.

With respect to the first characteristic, Gartner and Carter (2003) declare that we “... consider the processes of organization formation to be the core characteristics of entrepreneurship," and many appear to agree with them. However, this would seem imply that already-formed organizations cannot engage in entrepreneurial actions. But, there is no simply inherent reason why

\footnotetext{
6 Some contributions that are close to the RBV highlight individual cognition in structuring the search for new resource combinations (e.g. Amit \& Schoemaker, 1993), but such ideas do not seem to be well integrated into the core of the RBV.
} 
entrepreneurship thus defined cannot be exercised by established firms. Established firms regularly discover and exploit new opportunities. In fact, Schumpeter (1942) argued that entrepreneurship should be thought of as a firm-level phenomenon (see also Baumol, 1990). If entrepreneurship researchers have nevertheless often tied together new firm formation and entrepreneurship, this is presumably caused by new firm formation being an important driver of economic growth.

A second characteristic of the entrepreneurship literature is the concentration on individuals.. Organizations enter the analysis mainly as an instrument of the entrepreneur's vision. This contrasts with the evidence that a substantial number of new ventures are founded by entrepreneurial teams (e.g., Cooper \& Daily, 1997), that is, a group of entrepreneurs with a common goal that can only be realized by certain combinations of entrepreneurial actions (Harper, 2008).

The third characteristic of the more recent entrepreneurship literature is what is arguably an an over-concentration on opportunity discovery. Following Scott Shane's work (Shane, 2003), management research on entrepreneurship has made entrepreneurship virtually synonymous with opportunity discovery. However, there is clearly much more to entrepreneurship than the discovery of opportunities, namely the exploitation of those opportunities through assembling and deploying a bundle of relevant resources, such as complementary assets related to production, sales and marketing.

\section{Two Examples of Papers That Forge Linkages Between the RBV and Entrepreneurship}

One of the first papers to deal with the relation between (the high church) RBV and entrepreneurship is Elaine Mosakowski’s “Entrepreneurial Resources, Organizational Choices and Competitive Outcomes" (1998). She defines "entrepreneurial resources" as the "propensity of an individual to behave creatively, act with foresight, use intuition, and be alert to new opportunities" (p.625), and argues that such resources can be distributed in two ways in firms: Either they are held by a single manager-entrepreneur, or they are distributed across individuals in an entrepreneurial 
team. However, her main interest is in understanding the organizational embeddedness of such resources rather than their contribution to competitive advantage.

Sharon Alvarez and Lowell Busenitz (2001) is more directly forthcoming regarding how the RBV and entrepreneurship relates. They seek to extend the RBV by introducing "entrepreneurial recognition"- defined as both the recognition of opportunities and opportunity-seeking behaviour - as a resource. They also treat the "process of combining and organizing resources as a resource" (p.756). They analyze entrepreneurship thus understood in terms of the Peteraf (1993) framework. Thus, entrepreneurial recognition and resource organization are heterogeneous because they are based on different information, personal backgrounds, heuristics, and so on; they are given to ex post limits to competition, because they are rooted in path-dependent processes that are difficult to emulate and because they embody much tacit knowledge; and they are highly immobile, because they are typically linked to specific resource with which they co-specialize. Alvarez and Busenitz do not offer a discussion of Peteraf's final criterion, specifically that there must be ex ante limits to competition (except for a few very general remarks).

\section{STRATEGIC ENTREPRENEURSHIP}

The field of strategic entrepreneurship (henceforth, "SE") is a fairly recent one. Mainly associated with scholars like Michael Hitt and Duane Ireland, its central idea is that opportunity-seeking and advantage-seeking - the former the central subject of the entrepreneurship field, the latter the central subject of the strategic management field - are processes that need to be considered jointly. Establishing this link is particularly important in dynamic environments where advantages may be short-lived. SE involves going beyond the focus on start-ups, characteristic of the entrepreneurship field, and paying explicit attention to the established firm as a source of entrepreneurial actions. It also involves paying explicit attention of the creation of competitive advantages, a weak spot of the strategic management field. 
In one of the early conceptualization of strategic entrepreneurship Hitt and Ireland (2000) propose six different domains of intersection between strategic management and entrepreneurship: innovation, organizational networks, internationalization, organizational learning, top management teams and governance, and growth, flexibility and change.As this list indicates, the focus in this stream is on the enactment of entrepreneurial strategies "to continuously create competitive advantages that lead to maximum wealth creation" (Hitt et al., 2002: 2). There is a strong emphasis on the top management team and its strategic intent (Ireland, Hitt \& Sirmon, 2003; Ireland et al., 2001). However, not all entrepreneurial actions are the result of firms having enacted an entrepreneurial strategy. Entrepreneurial behaviors can emerge from lower levels of an organization (Burgelman, 1983), but this not yet seem to have incorporated in this research stream.

Ireland et al. $(2001,2003)$ discuss the determinants of organizational level "wealth creation": an entrepreneurial mindset, entrepreneurial culture and leadership, managing resources strategically, and applying creativity and developing innovation. However, many different variables at different levels of analysis are invoked in this research stream as determinants of wealth creation. A particularly influential construct is that of "entrepreneurial orientation" which originates before the advent of strategic entrepreneurship (Lumpkin \& Dess, 1996). An entrepreneurial orientation ”... refers to the strategy-making practices that businesses use to identify and launch corporate ventures" ( Dess \& Lumpkin, 2005: 147), and is is measured by five key entrepreneurial variables, namely autonomy, innovativeness, risk taking, proactiveness and competitive aggressiveness (Dess \& Lumpkin, 2005). Firms differ with respect to these variables (Ireland, Kuratko, \& Covin, 2003). Broadly defined, innovation is perhaps the most examined element of entrepreneurial orientation.

\section{CONCLUSIONS}

This chapter has examined the relations between strategic management, exemplified by the RBV, and the entrepreneurship field. While the RBV has concentrated on competitive advantages and 
their protection, the entrepreneurship field raises questions about the very origin of those advantages. Of course, not all opportunities become competitive advantages; they may exploited, the competition finds out, imitation ensures, etc., and the profit opportunity is competed away. But some do, and to extent that strategy is concerned with competitive advantages (and not just their sustainability), more attention needs to be paid to essentially entrepreneurial acts of creating or discovering opportunities.

Given the strongly complementary nature of the RBV and entrepreneurship, the existing amount of contact is not exactly overwhelming. There are many signs, however, that this is changing. Scholars associated with the RBV and its dynamic capabilities offspring are increasingly becoming interested in managerial cognition; they address those capabilities that dynamically act to change the firm's resource-base; they discuss the tradeoffs between exploiting existing activities and resources and exploring new activities and uses of existing resources; and so on. These developments have been going for almost fifteen years. Although they may have most explicitly related to innovation research, entrepreneurship and innovation are very strongly overlapping. For almost as long a group of scholars have been gathering under the "strategic entrepreneurship" banner, and have made strides forward in the attempt to link entrepreneurship to established firms (rather than just start-ups). They result of all this is that both strategy and entrepreneurship are changing. In fact, Baker and Pollock (2007: 297) argue that "strategy is succeeding in its takeover of the academic field of entrepreneurship." This may be overstating it, but it does point to the existence of a much closer liaison between strategy and entrepreneurship - to the benefit of both.

\section{FURTHER READING}

Anyone interested in the RBV should familiarize herself with the classical research papers, in particular Wernerfelt (1984), Barney $(1986,1991)$, and Peteraf (1993). These are quite accessible and are readable by most reasonably advanced students. More recent, and difficult, papers are 
Lippman and Rumelt (2003a, b), Denrell, Fang and Winter (2003), and Adegbesan (2009). The founding paper on core competences is Prahalad and Hamel (1990) and the founding dynamic capabilities paper is Teece, Pisano and Shuen (1997). Foss and Stieglitz (2011) summarizes the resource-based literature of various stripes. Foss (1997) is a collection of classical RBV papers, although it may now be a bit outdated.

In entrepreneurship, it pays to study one of the classics, notably Schumpeter $(1911,1942)$ or Kirzner (1973). Most students will find these somewhat tough going, particularly because they presuppose substantial knowledge about economics. More managerially oriented contributions by very influential scholars in the recent entrepreneurship literature are Shane (2003) and Sarasvathy (2007), representative of the "opportunity discovery" and "effectuation" approaches, respectively. The strategic entrepreneurship literature is discussed in Foss and Lyngsie (2012).

\section{QUESTIONS FOR DISCUSSION}

- A key concept in the RBV is the notion of a strategic factor market, that is, those markets where firms acquire resources that are necessary for realizing their strategies (Barney, 1986). Is entrepreneurship a resource that can be purchased on a strategic factor market?

- Entrepreneurs are usually thought of as individuals. In contrast, strategic management usually highlights top management teams. Discuss to what extent it makes sense to think of entrepreneurship as something that is exercised by a managerial team.

- Discuss the meaningfulness of the notion of "sustained competitive advantage" in the presence of (ongoing) entrepreneurship. 


\section{REFERENCES}

Acedo, F. J., Barroso, C. and Galan J. L. 2006. "The resource-based theory: Dissemination and main trends". Strategic Management Journal, 27: 621-636.

Adegbesan, A. J. 2009. "On the origins of competitive advantage: Strategic factor markets and heterogeneous resource complementarity". Academy of Management Review, 34: 463-475.

Alvarez, S.A. and Busenitz, L.W. 2001. "The entrepreneurship of resource-based theory". Journal of Management, 27: 755-775.

Amit, R. and Schoemaker, P. 1993. "Strategic assets and organizational rent". Strategic Management Journal, 14: 33-46.

Arend, R.J. 2006. "Tests of the resource-based view: do the empirics have any clothes?". Strategic Organization, 4: 409-421.

Armstrong, C.E. and Shimizu, K. 2007. "A Review of Approaches to Empirical Research on the Resource-Based View of the Firm”. Journal of Management, 33 (6): 959-986.

Baker, T. and Pollock, T.S. 2007. "Making the Marriage Work: The Benefits of Strategy's Takeover of Entrepreneurship for Strategic Organization.” Strategic Organization, 5(3): 297312.

Barney, J. B. 1986. "Strategic factor markets: Expectations, luck, and business strategy". Management Science, 32: 1231-1241.

Barney, J. B. 1991. "Firm resources and sustained competitive advantage". Journal of Management, 17: 99-120.

Baumol, W.J. 1990. "Entrepreneurship, productive, unproductive and destructive". Journal of Political Economy, 98 (5): 893-921.

Blyler, M. and Coff, R.W. 2003. "Dynamic Capabilities, Social Capital, and Rent Appropriation: Ties that Split Pies ". Strategic Management Journal, 24: 677-686.

Burgelman, R. 1983. "A process model of internal corporate venturing in the diversified major firms". Administrative Science Quarterly, 28: 223-244.

Casson, M. and Wadeson, N. 2007. "Entrepreneurship and macroeconomic performance". Strategic Entrepreneurship Journal, 1(3-4): 239-262.

Coase, R.H.1937. “The Nature of the Firm”. Economica, New Series, 4 (16): 386-405.

Coase, R.H. 1960. "The problem of Social Cost”. Journal of Law and Economics, 3:1-44.

Coff, R. 1997. "Human assets and management dilemmas: Coping with hazards on the road to resource-based theory". Acad. Management Rev. , 22(2): 374-402.

Coff, R. W. 1999. "When competitive advantage doesn't lead to performance: The resource-based view and stakeholder bargaining power". Organization Science, 10: 119-133.

Cohen, W.M and Levinthal, D.A. 1990. "Absorptive Capacity: A New Perspective on Learning and Innovation “. Administrative Science Quarterly, 35 (1):128-152.

Conner, K. 1991. "A Historical Comparison of Resource-based Theory and Five Schools of Thought within Industrial Organization Economics: Do We Have a New Theory of the Firm?”. Journal of Management, 17:121-154. 
Crook, T. R., Ketchen, D. J., Combs, J. G., and Todd, S. Y. 2008. "Strategic resources and performance: a meta-analysis". Strategic Management Journal, 29(11): 1141-1154.

Demsetz, H. 1973. "Industrial Structure, Market Rivalry, and Public Policy”, Journal of Law and Economics 16: 1-10.

Demsetz, H.. 1982. "Barriers to Entry”. In idem. 1989. Efficiency, Competition, and Policy. Oxford: Basil Blackwell.

Denrell, J., Fang, C. and Winter, S. G. 2003. "The Economic of Strategic Opportunity.” Strategic Management Journal, 24: 977-990.

Dess, G.G. and Lumpkin, G.T. 2005. "The role of entrepreneurial orientation in stimulating effective corporate entrepreneurship". Academy of Management Executive, 19: 147-156.

Dierickx, I. and Cool, K. 1989. "Asset Stock Accumulation and the Sustainability of Competitive Advantage". Management Science 35: 1504-11.

Eisenhardt, K.M, and Martin, J.A. 2000. "Dynamic Capabilities: What Are They? “. Strategic Management Journal, 21: 1105- 1121.

Foss, N. J. 1997. Resources, Firms, and Strategies. Oxford: Oxford University Press.

Foss, N.J. and Knudsen, T. 2003. "The resource-based tangle: towards a sustainable explanation of competitive advantage," Managerial and Decision Economics, John Wiley \& Sons, Ltd., 24(4): 291-307.

Foss, N. J., and Stieglitz 2011. "Modern Resource-based Theories," in M.E. Dietrich and J. Kraff, eds. 2011. Handbook on the Economics and Theory of the Firm. Edward Elgar.

Foss, N.J. \& Lyngsie, J. 2012. "Strategic Entrepreneurship," in D. Hjorth. 2012. Handbook of Organisational Entrepreneurship. Edward Elgar.

Gartner W. B. and Carter N. M. 2003. "Entrepreneurial Behavior and Firm Organizing Processes”. In: Acs, Z. J. and Audretch, D. B. (eds) Handbook of Entrepreneurship Research, pp. 195-221. Kluwer Academic Publishers, Boston

Gavetti, G. and Levinthal, D.A. 2004. "The strategy field from the perspective of management science: Divergent strands and possible integration". Management Science, 50: 1309-1318.

Harper, D.A. 2008. "Towards a theory of entrepreneurial teams". Journal of Business Venturing, 23 (6): 613-626.

Hayek, F.A. 1968. “Competition as a Discovery Procedure,” in idem. 1978. New Essays. London: Routledge.

Helfat, C.E. et al., 2007. Dynamic Capabilities: Understanding Strategic Change in Organizations. Oxford: Blackwell.

Helfat, C. E. and Peteraf, M. A. 2009. "Understanding dynamic capabilities: progress along a developmental path". Strategic Organization, 7: 91-102.

Hitt, M.A. and Ireland, R.D. 2000. "The intersection of entrepreneurship and strategic management research". In Handbook of Entrepreneurship, pp.45-63, Sexton, D.L. and Landstrom, H.A. (eds.). Blackwell: Oxford.

Hitt, M. A., Ireland, R. D., Camp, S. M. and Sexton, D. L. 2002. Strategic Entrepreneurship: Creating a New Mindset. Oxford and Malden, MA: Blackwell. 
Hoopes, D.G. and Madsen T. L. 2008. "A capability-based view of competitive heterogeneity". Industrial and Corporate Change, April: 1-34.

Hoskisson, R. E., Hitt, M. A., Wan, W. and Yiu, D. 1999. "Theory and research in strategic management: Swings of a pendulum". Journal of Management 25(3): 417-456.

Ireland R.D., Hitt, M.A., Camp, S.M., and Sexton, D.L. 2001. "Integrating entrepreneurship actions and strategic management actions to create firm wealth". Academy of Management Executive 15(1): 49-63.

Ireland, R.D., Hitt, M.A., and Sirmon, D.G. 2003. “A model of strategic entrepreneurship: The construct and its dimensions". Journal of Management, 29(6): 963-989.

Ireland, R.D., Kuratko, D.F., and Covin, J.G. 2003. “Antecedents, elements, and consequences of

Ireland, R. D., Hitt, M. A., Camp, S. M., and Sexton, D. L. 2001. Integrating Entrepreneurship and Strategic Management Actions to Create Firm Wealth. The Academy of Management Executive, 15: 49-63.

King, A.W. and Zeithaml, C.P. 2001. "Competencies and Firm Performance: Examining the Causal Ambiguity Paradox”. Strategic Management Journal, 22 (1): 75-99.

Kirzner, I. 1973. Competition and Entrepreneurship. Chicago and London: University of Chicago Press.

Knight, F. H. 1921. Risk, Uncertainty, and Profit. New York: August M. Kelley.

Knott, A. M., Bryce, D. J., \& Posen, H. E. 2003. "On the Strategic Accumulation of Intangible Assets". Organization Science, 14(2): 192-207.

Kogut, B. and Zander, U. 1992. "Knowledge of the firm, combinative capabilities, and the replication of technology". Organization Science, 3: 383-397.

Kor, Y. Y. and Mahoney, J. T. 2000. "Penrose's Resource-Based Approach: The Process and Product of Research Creativity." Journal of Management Studies 37(1): 109-39.

Langlois, R. N. 1992. “Transaction-cost Economics in Real Time”. Industrial and Corporate Change, 1: 99-127.

Lippman, S. A., and Rumelt, R. P. 1982. "Uncertain imitability: An analysis of interfirm differences in efficiency under competition". The Bell Journal of Economics, 13: 418-438.

Lippman, S. A., and Rumelt, R. P. 2003. "A bargaining perspective on resource advantage". Strategic Management Journal, 24: 1069-1086.

Lockett, A. and S. Thompson. 2001. "The Resource-based View and Economics". Journal of Management, 27: 723-724.

Lumpkin, G.T. and Dess, G.G., 1996. "Clarifying the entrepreneurial orientation construct and linking it to performance". Academy of Management Review, 21 (1): 135-172.

Makadok, R. 2001a. "A pointed commentary on Priem and Butler". Academy of Management Review, 26: 498-499.

Makadok, R. 2001b. "Toward a Synthesis of the Resource-Based and Dynamic-Capability Views of Rent Creation”. Strategic Management Journal 22: 387-401. 
Makadok, R. and Barney, J.B. 2001. "Strategic Factor Market Intelligence: An Application of Information Economics to Strategy Formulation and Competitor Intelligence". Management Science 47: 1621-1638.

Makadok, R. 2010. "The Interaction Effect of Rivalry Restraint and Competitive Advantage on Profit: Why the Whole Is Less Than the Sum of the Parts". Forthcoming in Management Science.

Mises, L.V. 1949. Human Action. New Haven: Yale University Press.

Mosakowski, E. 1998. "Entrepreneurial Resources, Organizational Choices, and Competitive Outcomes," Organization Science, 9: 625-643

Nelson, R. R., and Winter S. G. 1982. An evolutionary theory of economic change. Cambridge, MA: Belknap Press.

Newbert, S. L. 2007. "Empirical research on the resource-based view of the firm: An assessment and suggestions for future research”. Strategic Management Journal, 28: 121-147.

Penrose, Edith T. 1959. The Theory of the Growth of the Firm. Oxford: Oxford University Press.

Peteraf, M. A. 1993. "The cornerstones of competitive advantage: A resource-based view". Strategic Management Journal, 14: 179-191.

Peteraf, M. A., and Barney, J. B. 2003. "Unraveling the resource-based tangle". Managerial and Decision Economics, 24: 309-323.

Porter, M. 1980. Competitive strategy. New York: The Free Press.

Porter, Michael E .1981. "The Contribution of Industrial Organization to Strategic Management". Academy of Management Review 6(4).

Priem, R. L., and Butler, J. E. 2001a. "Is the resource-based "view" a useful perspective for strategic management research?". The Academy of Management Review, 26: 22-40.

Priem, R. L., and Butler, J. E. 2001. "Tautology in the resource-based view and the implications of externally determined resource value: Further comments". The Academy of Management Review, 26: 57-66

Reed, R. and Defillippi, R.J. 1990. "Causal Ambiguity, Barriers to Imitation, and Sustainable Competitive Advantage ".The Academy of Management Review, 15 (1): 88-102.

Rivkin, Jan. 2000. "Imitation of Complex Strategies". Management Science 46: 824-844.

Rumelt, R. P. 1984. "Towards a Strategic Theory of the Firm". In Richard B. Lamb, ed. Competitive Strategic Management, New Jersey: Englewood Cliffs.

Rumelt, R. P. 1987. "Theory, Strategy, and Entrepreneurship". In D. J. Teece (ed.). The Competitive challenge: Strategies for industrial innovation and renewal. 137-158. Cambridge, MA: Ballinger.

Rumelt, R.P., Schendel, D. and Teece, D.J. 1991. "Strategic Management and Economics". Strategic Management Journal, 12: 5-29.

Salerno, J.T. 1993. "Mises and Hayek Dehomogenized". Review of Austrian Economics, 6(2):11346.

Sarasvathy, S.D. 2008. Effectuation: Elements of Entrepreneurial Expertise. Edward Elgar.

Schumpeter, J. A. 1911. The Theory of Economic Development: An Inquiry into Profits, Capital, 
Credit, Interest, and the Business Cycle. Translated by Redvers Opie. Cambridge, Mass.: Harvard University Press, 1934.

Schumpeter, J.A. 1942. Capitalism, socialism, and democracy. NY: Harper.

Shane, Scott. 2000. "Prior Knowledge and the Discovery of Entrepreneurial Opportunities". Organization Science 11 (4): 448-469.

Shane, Scott 2003. A General Theory of Entrepreneurship: The Individual-Opportunity Nexus. Aldershot, UK: Edward Elgar.

Teece, D.J. 1986. "Profiting from technological innovation". Research Policy, 15: 286-305.

Teece, D. J., Pisano, G. and Shuen, A. 1997. "Dynamic Capabilities and Strategic Management". Strategic Management Journal 18(7): 509-533.

Teece, D.J. 2007. "Explicating dynamic capabilities: The nature and microfoundations of (sustainable) enterprise performance”. Strategic Management Journal 28: 1319-1350.

Wennekers, A.R.M. and Thurik, A.R. 1999. "Linking entrepreneurship and economic growth". Small Business Economics 13 (1): 27-55.

Wernerfelt, Birger. 1984. “A Resource-based View of the Firm”. Strategic Management Journal 5: 171-180.

Williamson, O.E. 1996 The Mechanisms of Governance. Oxford: Oxford University Press.

Winter, S. G. 2000. “The Satisficing Principle in Capability Learning”. Strategic Management Journal, 21(10/11): 981-996.

Winter, S.G. and Szulanski, G. 2001. "Replication as Strategy". Organization Science, 12 (6): 730743. 


\section{SMG - Working Papers \\ www.cbs.dk/smg \\ 2003}

2003-1: Nicolai J. Foss, Kenneth Husted, Snejina Michailova, and Torben Pedersen: Governing Knowledge Processes: Theoretical Foundations and Research Opportunities.

2003-2: Yves Doz, Nicolai J. Foss, Stefanie Lenway, Marjorie Lyles, Silvia Massini, Thomas P. Murtha and Torben Pedersen: Future Frontiers in International Management Research: Innovation, Knowledge Creation, and Change in Multinational Companies.

2003-3: Snejina Michailova and Kate Hutchings: The Impact of In-Groups and OutGroups on Knowledge Sharing in Russia and China CKG Working Paper.

2003-4: Nicolai J. Foss and Torben Pedersen: The MNC as a Knowledge Structure: The Roles of Knowledge Sources and Organizational Instruments in MNC Knowledge Management CKG Working Paper.

2003-5: Kirsten Foss, Nicolai J. Foss and Xosé H. Vázquez-Vicente: “Tying the Manager's Hands": How Firms Can Make Credible Commitments That Make Opportunistic Managerial Intervention Less Likely CKG Working Paper.

2003-6: Marjorie Lyles, Torben Pedersen and Bent Petersen: Knowledge Gaps: The Case of Knowledge about Foreign Entry.

2003-7: Kirsten Foss and Nicolai J. Foss: The Limits to Designed Orders: Authority under "Distributed Knowledge" CKG Working Paper.

2003-8: Jens Gammelgaard and Torben Pedersen: Internal versus External Knowledge Sourcing of Subsidiaries - An Organizational Trade-Off.

2003-9: Kate Hutchings and Snejina Michailova: Facilitating Knowledge Sharing in Russian and Chinese Subsidiaries: The Importance of Groups and Personal Networks Accepted for publication in Journal of Knowledge Management.

2003-10: Volker Mahnke, Torben Pedersen and Markus Verzin: The Impact of Knowledge Management on MNC Subsidiary Performance: the Role of Absorptive Capacity CKG Working Paper.

2003-11: Tomas Hellström and Kenneth Husted: Mapping Knowledge and Intellectual Capital in Academic Environments: A Focus Group Study Accepted for publication in Journal of Intellectual Capital CKG Working Paper.

2003-12: Nicolai J Foss: Cognition and Motivation in the Theory of the Firm: Interaction or "Never the Twain Shall Meet"? Accepted for publication in Journal des Economistes et des Etudes Humaines CKG Working Paper.

2003-13: Dana Minbaeva and Snejina Michailova: Knowledge Transfer and Expatriation Practices in MNCs: The Role of Disseminative Capacity.

2003-14: Christian Vintergaard and Kenneth Husted: Enhancing Selective Capacity Through Venture Bases. 


\section{4}

2004-1: Nicolai J. Foss: Knowledge and Organization in the Theory of the Multinational Corporation: Some Foundational Issues

2004-2: Dana B. Minbaeva: HRM Practices and MNC Knowledge Transfer

2004-3: Bo Bernhard Nielsen and Snejina Michailova: Toward a Phase-Model of Global Knowledge Management Systems in Multinational Corporations

2004-4: Kirsten Foss \& Nicolai J Foss: The Next Step in the Evolution of the RBV: Integration with Transaction Cost Economics

2004-5: Teppo Felin \& Nicolai J. Foss: Methodological Individualism and the Organizational Capabilities Approach

2004-6: Jens Gammelgaard, Kenneth Husted, Snejina Michailova: Knowledge-sharing Behavior and Post-acquisition Integration Failure

2004-7: Jens Gammelgaard: Multinational Exploration of Acquired R\&D Activities

2004-8: Christoph Dörrenbächer \& Jens Gammelgaard: Subsidiary Upgrading? Strategic Inertia in the Development of German-owned Subsidiaries in Hungary

2004-9: Kirsten Foss \& Nicolai J. Foss: Resources and Transaction Costs: How the Economics of Property Rights Furthers the Resource-based View

2004-10: Jens Gammelgaard \& Thomas Ritter: The Knowledge Retrieval Matrix: Codification and Personification as Separate Strategies

2004-11: Nicolai J. Foss \& Peter G. Klein: Entrepreneurship and the Economic Theory of the Firm: Any Gains from Trade?

2004-12: Akshey Gupta \& Snejina Michailova: Knowledge Sharing in Knowledge-Intensive Firms: Opportunities and Limitations of Knowledge Codification

2004-13: Snejina Michailova \& Kate Hutchings: Knowledge Sharing and National Culture: A Comparison Between China and Russia

\section{5}

2005-1: Keld Laursen \& Ammon Salter: My Precious - The Role of Appropriability Strategies in Shaping Innovative Performance

2005-2: Nicolai J. Foss \& Peter G. Klein: The Theory of the Firm and Its Critics: A Stocktaking and Assessment

2005-3: Lars Bo Jeppesen \& Lars Frederiksen: Why Firm-Established User Communities Work for Innovation: The Personal Attributes of Innovative Users in the Case of Computer-Controlled Music

2005-4: Dana B. Minbaeva: Negative Impact of HRM Complementarity on Knowledge Transfer in MNCs

2005-5: Kirsten Foss, Nicolai J. Foss, Peter G. Klein \& Sandra K. Klein: Austrian Capital 
Theory and the Link Between Entrepreneurship and the Theory of the Firm

2005-1: Nicolai J. Foss: The Knowledge Governance Approach

2005-2: Torben J. Andersen: Capital Structure, Environmental Dynamism, Innovation Strategy, and Strategic Risk Management

2005-3: Torben J. Andersen: A Strategic Risk Management Framework for Multinational Enterprise

2005-4: Peter Holdt Christensen: Facilitating Knowledge Sharing: A Conceptual Framework

2005-5 Kirsten Foss \& Nicolai J. Foss: Hands Off! How Organizational Design Can Make Delegation Credible

2005-6 Marjorie A. Lyles, Torben Pedersen \& Bent Petersen: Closing the Knowledge Gap in Foreign Markets - A Learning Perspective

2005-7 Christian Geisler Asmussen, Torben Pedersen \& Bent Petersen: How do we Capture "Global Specialization" when Measuring Firms' Degree of internationalization?

2005-8 Kirsten Foss \& Nicolai J. Foss: Simon on Problem-Solving: Implications for New Organizational Forms

2005-9 Birgitte Grøgaard, Carmine Gioia \& Gabriel R.G. Benito: An Empirical Investigation of the Role of Industry Factors in the Internationalization Patterns of Firms

2005-10 Torben J. Andersen: The Performance and Risk Management Implications of Multinationality: An Industry Perspective

2005-11 Nicolai J. Foss: The Scientific Progress in Strategic Management: The case of the Resource-based view

2005-12 Koen H. Heimeriks: Alliance Capability as a Mediator Between Experience and Alliance Performance: An Empirical Investigation Into the Alliance Capability Development Process

2005-13 Koen H. Heimeriks, Geert Duysters \& Wim Vanhaverbeke: Developing Alliance Capabilities: An Empirical Study

2005-14 JC Spender: Management, Rational or Creative? A Knowledge-Based Discussion

\section{6}

2006-1: Nicolai J. Foss \& Peter G. Klein: The Emergence of the Modern Theory of the Firm

2006-2: Teppo Felin \& Nicolai J. Foss: Individuals and Organizations: Thoughts on a Micro-Foundations Project for Strategic Management and Organizational Analysis

2006-3: Volker Mahnke, Torben Pedersen \& Markus Venzin: Does Knowledge Sharing 
Pay? An MNC Subsidiary Perspective on Knowledge Outflows

2006-4: Torben Pedersen: Determining Factors of Subsidiary Development

2006-5 Ibuki Ishikawa: The Source of Competitive Advantage and Entrepreneurial Judgment in the RBV: Insights from the Austrian School Perspective

2006-6 Nicolai J. Foss \& Ibuki Ishikawa: Towards a Dynamic Resource-Based View: Insights from Austrian Capital and Entrepreneurship Theory

2006-7 Kirsten Foss \& Nicolai J. Foss: Entrepreneurship, Transaction Costs, and Resource Attributes

2006-8 Kirsten Foss, Nicolai J. Foss \& Peter G. Klein: Original and Derived Judgement: An Entrepreneurial Theory of Economic Organization

2006-9 Mia Reinholt: No More Polarization, Please! Towards a More Nuanced Perspective on Motivation in Organizations

2006-10 Angelika Lindstrand, Sara Melen \& Emilia Rovira: Turning social capital into business? A study of Swedish biotech firms' international expansion

2006-11 Christian Geisler Asmussen, Torben Pedersen \& Charles Dhanaraj: Evolution of Subsidiary Competences: Extending the Diamond Network Model

2006-12 John Holt, William R. Purcell, Sidney J. Gray \& Torben Pedersen: Decision Factors Influencing MNEs Regional Headquarters Location Selection Strategies

2006-13 Peter Maskell, Torben Pedersen, Bent Petersen \& Jens Dick-Nielsen: Learning Paths to Offshore Outsourcing - From Cost Reduction to Knowledge Seeking

2006-14 Christian Geisler Asmussen: Local, Regional or Global? Quantifying MNC Geographic Scope

2006-15 Christian Bjørnskov \& Nicolai J. Foss: Economic Freedom and Entrepreneurial Activity: Some Cross-Country Evidence

2006-16 Nicolai J. Foss \& Giampaolo Garzarelli: Institutions as Knowledge Capital: Ludwig M. Lachmann's Interpretative Institutionalism

2006-17 Koen H. Heimriks \& Jeffrey J. Reuer: How to Build Alliance Capabilities

2006-18 Nicolai J. Foss, Peter G. Klein, Yasemin Y. Kor \& Joseph T. Mahoney: Entrepreneurship, Subjectivism, and the Resource - Based View: Towards a New Synthesis

2006-19 Steven Globerman \& Bo B. Nielsen: Equity Versus Non-Equity International Strategic Alliances: The Role of Host Country Governance

\section{7}

2007-1 Peter Abell, Teppo Felin \& Nicolai J. Foss: Building Micro-Foundations for the Routines, Capabilities, and Performance Links 
2007-2 Michael W. Hansen, Torben Pedersen \& Bent Petersen: MNC Strategies and Linkage Effects in Developing Countries

2007-3 Niron Hashai, Christian G. Asmussen, Gabriel R.G. Benito \& Bent Petersen: Predicting the Diversity of Foreign Entry Modes

2007-4 Peter D. Ørberg Jensen \& Torben Pedersen: Whether and What to Offshore?

2007-5 Ram Mudambi \& Torben Pedersen: Agency Theory and Resource Dependency Theory: Complementary Explanations for Subsidiary Power in Multinational Corporations

2007-6 Nicolai J. Foss: Strategic Belief Management

2007-7 Nicolai J. Foss: Theory of Science Perspectives on Strategic Management Research: Debates and a Novel View

2007-8 Dana B. Minbaeva: HRM Practices and Knowledge Transfer in MNCs

2007-9 Nicolai J. Foss: Knowledge Governance in a Dynamic Global Context: The Center for Strategic Management and Globalization at the Copenhagen Business School

2007-10 Paola Gritti \& Nicolai J. Foss: Customer Satisfaction and Competencies: An Econometric Study of an Italian Bank

2007-11 Nicolai J. Foss \& Peter G. Klein: Organizational Governance

2007-12 Torben Juul Andersen \& Bo Bernhard Nielsen: The Effective Ambidextrous Organization: A Model of Integrative Strategy Making Processes.

\section{8}

2008-1 Kirsten Foss \& Nicolai J. Foss: Managerial Authority When Knowledge is Distributed: A Knowledge Governance Perspective

2008-2 Nicolai J. Foss: Human Capital and Transaction Cost Economics.

2008-3 Nicolai J. Foss \& Peter G. Klein: Entrepreneurship and Heterogeneous Capital.

2008-4 Nicolai J. Foss \& Peter G. Klein: The Need for an Entrepreneurial Theory of the Firm.

2008-5 Nicolai J. Foss \& Peter G. Klein: Entrepreneurship: From Opportunity Discovery to Judgment.

2008-6 Mie Harder: How do Rewards and Management Styles Influence the Motivation to Share Knowledge?

2008-7 Bent Petersen, Lawrence S. Welch \& Gabriel R.G. Benito: Managing the Internalisation Process - A Theoretical Perspective.

2008-8 Torben Juul Andersen: Multinational Performance and Risk Management Effects: Capital Structure Contingencies. 
2008-9 Bo Bernard Nielsen: Strategic Fit and the Role of Contractual and Procedural Governance in Alliances: A Dynamic Perspective.

2008-10 Line Gry Knudsen \& Bo Bernhard Nielsen: Collaborative Capability in R\&D Alliances: Exploring the Link between Organizational and Individual level Factors.

2008-11 Torben Juul Andersen \& Mahesh P. Joshi: Strategic Orientations of Internationalizing Firms: A Comparative Analysis of Firms Operating in Technology Intensive and Common Goods Industries.

2008-12 Dana Minbaeva: HRM Practices Affecting Extrinsic and Intrinsic Motivation of Knowledge Receivers and their Effect on Intra-MNC Knowledge Transfer.

2008-13 Steen E. Navrbjerg \& Dana Minbaeva: HRM and IR in Multinational Corporations: Uneasy Bedfellows?

2008-14 Kirsten Foss \& Nicolai J. Foss: Hayekian Knowledge Problems in Organizational Theory.

2008-15 Torben Juul Andersen: Multinational Performance Relationships and Industry Context.

2008-16 Larissa Rabbiosi: The Impact of Subsidiary Autonomy on MNE Knowledge Transfer: Resolving the Debate.

2008-17 Line Gry Knudsen \& Bo Bernhard Nielsen: Organizational and Individual Level Antecedents of Procedural Governance in Knowledge Sharing Alliances.

2008-18 Kirsten Foss \& Nicolai J. Foss: Understanding Opportunity Discovery and Sustainable Advantage: The Role of Transaction Costs and Property Rights.

2008-19 Teppo Felin \& Nicolai J. Foss: Social Reality, The Boundaries of Self-fulfilling Prophecy, and Economics.

2008-20 Yves Dos, Nicolai J. Foss \& José Santos: A Knowledge System Approach to the Multinational Company: Conceptual Grounding and Implications for Research

2008-21 Sabina Nielsen \& Bo Bernhard Nielsen: Why do Firms Employ foreigners on Their Top Management Teams? A Multi-Level Exploration of Individual and Firm Level Antecedents

2008-22 Nicolai J. Foss: Review of Anders Christian Hansen's “Uden for hovedstrømmen - Alternative strømninger i økonomisk teori"

2008-23 Nicolai J. Foss: Knowledge, Economic Organization, and Property Rights

2008-24 Sjoerd Beugelsdijk, Torben Pedersen \& Bent Petersen: Is There a Trend Towards Global Value Chain Specialization? - An Examination of Cross Border Sales of US Foreign Affiliates 
2008-25 Vikas Kumar, Torben Pedersen \& Alessandro Zattoni: The performance of business group firms during institutional transition: A longtitudinal study of Indian firms

2008-26 Sabina Nielsen \& Bo B. Nielsen: The effects of TMT and Board Nationality Diversity and Compensation on Firm Performance

2008-27 Bo B. Nielsen \& Sabina Nielsen: International Diversification Strategy and Firm Performance: A Multi-Level Analysis of Firm and Home Country Effects

\section{9}

2009-1 Nicolai J. Foss: Alternative Research Strategies in the Knowledge Movement: From Macro Bias to Micro-Foundations and Multi-Level Explanation

2009-2 Nicolai J. Foss \& Peter G. Klein: Entrepreneurial Alertness and Opportunity Discovery: Origins, Attributes, Critique

2009-3 Nicolai J. Foss \& Dana B. Minbaeva: Governing Knowledge: The Strategic Human Resource Management Dimension

2009-4 Nils Stieglitz \& Nicolai J. Foss: Opportunities and New Business Models: Transaction Cost and Property Rights Perspectives on Entrepreneurships

2009-5 Torben Pedersen: Vestas Wind Systems A/S: Exploiting Global R\&D Synergies

2009-6 Rajshree Agarwal, Jay B. Barney, Nicolai J. Foss \& Peter G. Klein: Heterogeneous Resources and the Financial Crisis: Implications of Strategic Management Theory

2009-7 Jasper J. Hotho: A Measure of Comparative Institutional Distance

2009-8 Bo B. Nielsen \& Sabina Nielsen: The Impact of Top Management Team Nationality Diversity and International Experience on Foreign Entry Mode

2009-9 Teppo Felin \& Nicolai Juul Foss: Experience and Repetition as Antecedents of Organizational Routines and Capabilities: A Critique of Behaviorist and Empiricist Approaches

2009-10 Henk W. Volberda, Nicolai J. Foss \& Marjorie E. Lyles: Absorbing the Concept of Absorptive Capacity: How To Realize Its Potential in the Organization Field

2009-11 Jan Stentoft Arlbjørn, Brian Vejrum Wæhrens, John Johansen \& Torben Pedersen: Produktion i Danmark eller offshoring/outsourcing: Ledelsesmæssige udfordringer 


\section{0}

2010-1 Dana B. Minbaeva, Kristiina Mäkelä \& Larissa Rabbiosi: Explaining Intraorganizational Knowledge Transfer at the Individual Level

2010-2 Dana B.Minbaeva \& Torben Pedersen: Governing Individual Knowledge Sharing Behavior

2010-3 Nicolai J. Foss \& Peter G. Klein: Alertness, Judgment, and the Antecedents of Entrepreneurship

2010-4 Nicolai J.Foss \& Joseph T.Mahoney: Exploring Knowledge Governance

2010-5 Jasper J. Hotho, Florian Becker-Ritterspach \& Ayse Saka-Helmhout: Enriching Absorptive Capacity Through Social Interaction

2010-6 Nicolai J. Foss \& Bo B. Nielsen: Researching Collaborative Advantage: Some Conceptual and Multi-level Issues

2010-7 Nicolai J. Foss \& Nils Stieglitz: Modern Resource-Based Theory(ies)

2010-8 Christian Bjørnskov \& Nicolai J. Foss: Do Economic Freedom and Entrepreneurship Impact Total Factor Productivity?

2010-9 Gabriel R.G. Benito, Bent Petersen \& Lawrence S. Welch: Mode Combinations and International Operations: Theoretical Issues and an Empirical Investigation

\section{1}

2011-1 Peter D. Ørberg Jensen \& Bent Petersen: Human Asset Internalization and Global Sourcing of Services - A Strategic Management Analysis on Activity-level

2011-2 Mie Harder: Management Innovation Capabilities: A Typology and Propositions for Management Innovation Research

2011-3 Mie Harder: Internal Antecedents of Management Innovation: The effect of diagnostic capability and implementation capability 
2011-4 Mie Harder: Explaining Management Innovation Pervasiveness: The Role of Internal Antecedents

2011-5 Mie Harder: Internal Determinants of Product Innovation and Management Innovation: The Effect of Diagnostic Capability and Implementation Capability

2011-6 Nicolai J. Foss, Peter G. Klein \& Per L. Bylund: Entrepreneurship and the Economics of the Firm

2011-7 Nicolai J. Foss \& Jacob Lyngsie: The Emerging Strategic Entrepreneurship Field: Origins, Key Tenets and Research Gaps

2011-8 Nicolai J. Foss: Entrepreneurship in the Context of the Resource-based View of the Firm 